\title{
Flensborg lærde og real-skole
}

\author{
Tysk - slesvig-bolstensk - dansk \\ slesvig-holstensk - preussisk
}

\section{Af Kjeld Galster}

Flensborg.

1 Flensborg var man patrioter. Man talte nok tysk, men man var den danske konges undersătter. Dannebrag var hejst, når Flensborg-skuden sejlede op i Nordhavet på hvalfangst, og når kursen gik syd, vest og østpå til Kina og Vestindien. Under det danske flag kom rigdommene hjem. Landet syd for Eideren, også Holsten altså, var Hamborgs handelsdomæne.

Man var ikke tysknational, ikke dansk, man var slesviger fra Flensborg, følte sig knyttet til det danske monarki, helstaten, man var statsborgerlig sindet, man var loyal.

Men i 1830erne og 40erne begyndte en ny tid så småt.

I typograf Kastrups bogtrykkeri blev Dannevirke fremstillet, og han udgav fra 1840 Flensburger Zeitung, støttet af Flor og Mancicus, mens konrektor G. E. Th. Francke, Flors ældste ven i byen, tilså og rettede sproget. Den mand, der betød mest, var dog hjulmager Kruse med det gode humør. Særlig blandt håndværkerne vandt han frem. Han gav sine følelser udtryk i et blomstrende sprog, som han havde lært af konrektor Francke, (der 1837 havde udgivet Der Skalde):

Dänemark! Vaterland! Brudervolk schwört,

Weltall es hört:

Liebe - Dir! fortan in Glückszeit und Noth!

Liebe - Dir, gilt's auch auf Leben und Tot!

Dänemark! Vaterland! uralter Leu!

Hehr, stark und treu -

Skalden einst sangen des Heldenvolks Muth,

Rümlichst noch floss jüngst Altdanias Bluth!

Men samtidig var også en tysk national bevægelse opstået 
under ledelse af advokat Bremer. Han søgte at vinde indflydelse i de forskellige borgerforeninger, han stiftede en Liedertafel. Det danske flag var en „Butterbrotsfahne“, banneret skulde være schwarz-rot-golden og blau-weiss-rot.

Til dette parti hørte omtrent hele embedsstanden: amtmanden, herredsfogderne, magistraten, post- og toldpersonalet, præsterne, lærerne ved borgerskolen og ved den larde skole (undtagen een).

Det åbne brev var blevet udstedt 8. juli 1846. Da kongen kort efter kom til Flensborg, blev han mødt med en folkeyndest, som han ellers ikke var vant til; men politikontoret meddeler, at enkelte skarer vedholdende havde sunget Schleswig-Holstein meerumschlungen i gaderne. ${ }^{1}$ )

Den dansksindede konrektor.

I tiden før 1848 havde Flensborg larde skole ligesom byen selv kun været lidet berørt af de nationale rørelser, slesvigholstenske eller danske.

Men da rejsningen kom, forandredes det, vandene skiltes. Efter slaget ved Bov så man slesvig-holstenerne flygte gennem byens gader, og nu, midt $\mathrm{i}$ april, håbede man på eller frygtede man prøjsernes indmarsch.

I Flensborg lærde skole havde rektoren, Hermann Koester ligesom lærerne deres sympati på oprørernes side. Kun konrektoren, dr. G. E. Th. Francke indtog en særstilling.

Han var født i Husum, søn af rektoren der, og havde studeret i Kiel. Men han tilhørte helstaten, var kongens undersåt, loyal, desuden dansk gift og medlem af oldskriftselskabet.

$\mathrm{Nu}$, noget efter midten af april, kom han til rektor Koester og anmodede om 8 dages orlov for at rejse til Sjælland. Først nægtede rektoren ham den. Et lærermøde blev så afholdt, rektor indvilgede, men Francke meddelte, at han allerede havde indsendt andragende til den nye kultusminister i København, Mon-

1) Kilderne til denne korte indledning er P. Lauridsen: Da Sønderjylland vågnede VII (1922) 110 ff. og Elisabeth Kardel: Die Stadt Fl. u. die pol. u. nat. Strömungen um die Mitte des 19. Jahrh. 
rad, om 3 måneders orlov. Rektoren hævdede, at han gjorde sig skyldig i ulovlighed, han kunde meddele hr. ministeren, at denne ingen ret havde til at give orlov uden rektorens tilslutning, og at såvel den, der under sådanne omstændigheder søgte orlov, som den, der fik orlov, handlede mod sin pligt.

Få dage derefter var de fjendtlige tropper i byen. Dr. Francke rejste.

21. juni skrev han fra Vognserup ved Holbæk til sin rektor. ${ }^{2}$ )

„Jeg tillader mig pligtskyldigst at meddele, at der under 19. ds. fra det kgl. slesvig-holstenske kancelli ${ }^{3}$ ) er tilstillet mig en skrivelse, i følge hvilken dette ,ikke haver nogen betænkelighed ved efter omstændighederne at forlænge min orlov til slutningen af juli, eventuelt til Flensborg er rømmet af fjendtlige tropper.

Idet jeg gentager min allerede tidligere udtalte beklagelse over at måtte forvolde Dem og de øvrige herrer kolleger ulejlighed, er jeg overbevist om, at De vil undskylde mig i betragtning af umuligheden af under de hidtidige omstændigheder at vende tilbage til mit embede. I det håb ved en velsignelsesrig genoprettelse af ro og orden derovre ret snart at blive ført tilbage til Deres kreds og håbende på venlig optagelse hos Dem kan jeg ikke undlade samtidig at sige Dem, hvor styrkende og opmuntrende opholdet på det velsignede Sjælland har virket på min sundhed efter så langvarigt arbejde og bekymring."

8. juli afskedigedes han af Den provisoriske regering. Men man må formode, at meddelelsen herom ikke er kommet ham i hænde; i hvert fald sendte han 15 . september 1848 sin rektor følgende skrivelse:

„Da endelig forholdene synes at udvikle sig mod fred (friedlich), ${ }^{4}$ ) og derfor det tidspunkt, da Flensborg er befriet for de mod den danske regering fjendtlige tropper og således min orlov vil være udløbet, snart er kommet, så tillader jeg mig den venlige bøn, at De godhedsfuld vil underrette mig, såsnart

2) Byarkivet, Flensborg.

a) I København.

4) Der var våbenstilstand. 
dette tidspunkt er kommet, da jeg som tro undersåt af min konge igen kan træde til i min embedsvirksomhed. I løbet af få dage vil jeg da kunne ordne mine sager her for at tiltræde mit embede. Jeg har derfor allerede forladt mit opholdssted på landet og bliver her i København for straks at kunne træffe mine foranstaltninger."

Brevene har ikke smagt de slesvig-holstenske øvrigheder, og da Francke modtog en fornyet meddelelse fra Den provisoriske regering (23. sept.), at han var afskediget, har det vist været med et smil; han havde selv villet det.

23. sept. 1849 beskikkedes han til sognepræst for Stenmagle og Stenlille.

Den slesvig-holstenske rektor.

Koester, der vel næppe havde den fornødne energi i disse bevægede tider, forflyttedes 15 . september 1848 sydpå til Plön. I hans sted ansattes Friedrich Lübker; med ham fulgte som konrektor hans kollega fra Slesvig domskole Schumacher; to andre nye kom samtidig til: dr. Mommsen og dr. Gidionsen.

Lübker var født i Husum 1811, søn af kompastor D. L. L. Allerede mens han gik i latinskole i sin fødeby, optrådte han offentlig som skribent, 16 år gammel. Under sine studieår i Kiel blev han to gange prisbelønnet for afhandlinger. Medens han læste i Kiel, faldt Uwe Lornsens virksomhed for et SlesvigHolsten, og det har sikkert påvirket ham. Efter et studieår i Berlin tog han den filosofiske doktorgrad i Kiel, og efter en kort tid ved Husum latinskole ansattes han, 24 år gammel, som konrektor ved Slesvig domskole, og nu, han var 37 år, kaldte Den provisoriske regering ham altså til Flensborg som rektor.

Med ham kom der en ny tid til Flensborg gamle skole. Slesvig-Holsten var hans fædreland, Danmark fjendeland. Han var fyldt af tidens tysk-national-liberale ideer, begejstret og fanatisk.

I disse bevægede år blev hans ånd skolens.

Seks af hans store disciple meldite sig i disse år til den slesvig-holstenske hær. 
D. 26. marts 1848 havde magistraten og de deputerede anerkendt Den provisoriske regering i Slesvig.

De ledende var borgmester Callisen, politimester Niemann og byrådssekretær Holm.

Der havde været en del uroligheder $\mathbf{i}$ byen. Af regeringen var en ivrig slesvig-holstener, Friedric von Krohn, blevet indsat som politisk politimester, og han var gået frem med hård hånd mod de danske demonstranter.")

$\mathrm{Nu}$, efter at våbenstilstanden var blevet sluttet med Preussen 10. juli 1849 og Nordslesvig var blevet besat af svenske tropper, skulde Siesvig foreløbig styres af en forvaltningskommission, bestående af danskeren Tillisch, preuseren Eulenburg og englænderen Hodges.

Denne indsatte som overpræsident og borgmester den håndfaste Gustav Lassen.

Gustav Lassen (1801-54) var født i Haderslev og student derfra. I 1844 var han blevet borgmester i sin fødeby og var i foråret 1848 blevet tvunget bort af slesvig-holstenerne. 22. April klev han (sammen med stiftamtmand Sponneck og konferensråd Kirstein) udnævnt til medlem af den provisoriske regeringskommission for hertugdømmet Slesvig, hvis opgave det var at forsøge at føre embedsmændene tilbage til pligt og troskab. $\mathrm{Nu}$ blev han altså overpræsident i Flensborg.

Krohn afskedigedes, og danskeren Schrader udnævntes til politimester.

Vi kan lade rektor Lübker selv skildre begivenhederne og udviklingen - som han nu så det: $:^{6}$ )

„Efter det lumske overfald ved Fredericia og den skammelige våbenstilstand fremstod der af den almindelige forbitrelse en stadig større tillid til en højlydt bekendelse af tysk sindelag, og det tog ved det fra oven øvede tryk til i stigende grad. At under sådanne forhold en højere læreanstalt, der netop griber ind i det indre liv i denne kreds, måtte øve en stor indflydelse, er forklarligt; den lærde skole havde siden sin reorganisation

5) P. Lauridsen: Mellem slagene. Sønderj. årbøger. 1899, s. 211.

) Pädagogische Revue. Zürich 1850. s. 222. 
hasten 1849 i påfaldende grad' vundet i tillid fra befolkningens side, havde $\mathrm{i}$ godt et år næsten fordoblet tallet paa elever og tjente samtidig i sine mellemklasser ved særlige foranstaltninger som realskole, som man tidligere havde tænkt at oprette som særskole. Lærerne havde også været ivrige for i videre kredse at virke for ... udbredelsen af tysk dannelse og sindelag. Navnlig havde de sidste vinter i gymnasiets høresale hver torsdag aften, for en større kreds af tilhørere af begge køn, holdt en række foredrag om tysk historie og litteratur . . . Begribeligvis blev denne skonne, velsignelsesrige virksomhed snart genstand for dansk had og forfølgelsessyge. Et forsøg fra danske underlægers side, der til ærgrelse for de svenske overlæger var anbragt ved de neutrale troppers hospitaler, på at gøre den store og veludstyrede skolebygning til lazaret, strandede, og også fra anden side var det svært at komme gymnasiet til livs. Lærerkollegiet havde, straks da våbenstilstands-regeringen trådte til, sammen med landets samtlige verdslige og gejstlige embedsmænd, afgivet den offentlige erklæring, at det som retmæssig regering kun anerkendte det af den tyske centralmagt (i Frankfurt am Main) indsatte statholderskab for Slesvig-Holsten, indtil afslutningen af en definitiv fred med Danmark, og derfor kun vilde følge den faktiske magthaver $i$ udførelsen af sit kald, for så vidt dette var foreneligt med pligt og samvittighed.“

To adresser blev skrevet; en rettet til den prøjsiske kommissær i Flensborg, grev Eulenburg, en til kongen af Prøjsen. Begge skulde godtgøre, at Flensborg i snævreste tilslutning til hele landets bestræbelser i forsvar for dets hårdt krænkede rettigheder stod urokkelig fast ved sit tyske sindelag og sin tilslutning til de ældgamle forbindelser Schleswig med Holstein.

Begge adresser var forfattet af Lübker.

I efteråret $1849 \mathrm{kom}$ det til demonstrationer, nu af tyskere, cg de blev slået ned af Lassen og Schrader — vel med lige så hård hånd, som Krohn havde brugt mod de danske.

Det kogte i Lübker. Alt det oprørende, som han syntes han oplevede, måtte han tage til orde imod - og sidst på året udkom anonymt (på et holstensk Schnellpressedruckerei) en piece: 
Schleswigsche Zustände. Mitteilung an die deutschen Fürsten und das deutsche Volk.

Skriftet bærer tydeligt præg af, at det er blevet til i en by og $i$ en tid, hvor man sloges i gaderne. Det er et fanatisk kampskrift, der handler om de ædle, forfulgte tyskere og de hensynslose, brutale danskere.

Lige efter at piecen var udkommet, kom det atter, nytårsaften 1849, til sammenstød med det danske politi. Slesvigholstenske borgere holdt omgående møde og sendte en deputation på fem til overpræsident Lassens kontor for at klage. Ordfører var også her Lübker. Han forlangte, at de politibetjente, der havde bevist, at de kun forstod at bruge deres våben til mishandling af uskyldige og værgeløse borgere (som han udtrykte sig) skulde fjernes. Da man ikke rettede sig efter kravet, henvendte han og de andre sig til den nye Landes-Verwaltung: Man krævede, at politimesteren og hans bevæbnede drabanter, skulde fjernes; hvis ikke vilde man vore nodt til at vobne sig for at beskytte sig selv, sin familie og sin ejendom.

Medens dette stod på, stod rektor Lübker på årets første skoledag på katedret og talte til ungdommen. ${ }^{7}$ )

„. . . Se på de to sidst forløbne år! - et så forskelligt broderpar! Det ene var en yngling, fuld af svulmende mod. Det andet en olding, der havde levet alt for stærkt og derfor mistet sit livs kraft.

Og når nu efter ynglingen oldingen er fulgt så brat, hvad for håb vil da nu det kommende år bringe os? For eder og os alle svæve billedet af en kraftig, helstøbt mand (eines ganzen, vollen Mannes Bild); .. efter den stormende begejstring, efter den lammende afspænding, blomstrer den friske, ædle dådskraft frem; jeg ønsker, at $\mathrm{i}$ den vildt bevægede tids storm vort hjerte må blive (werde) fast. Det give Gud ved sin nåde ...."

Men var ophidselsen stor paa tysk side, så var den ikke mindre hos danskerne. s. 42 .

7) Religionsblatt für die Herzogtümer Schl. H. u. Lauenburg. 1850 
4. januar, da man var midt i begivenhederne, skrev Lassen (på tysk) til Kirstein" ${ }^{*}{ }^{8}$ )

„For øjeblikket er jeg $\mathrm{i}$ en så ophidset sindstemning, at jeg næppe formår at skrive." Det kommunale politi ledes af politimester Niemann og byrådssekretær Holm ... „Niemann er en svag mand, men ivrig slesvig-holstener, og et blindt værktøj for den snu Holm; Niemann skal afsættes, og nu vil „Lands-styrelsen", at jeg foreløbig skal overtage politiembedet her, for Niemann; jeg kæmper en svær kamp; jeg tilstår — også med min forfængelighed. Til sidst må jeg vel ogsaa bringe dette offer; jeg kender intet passende emne. $\mathrm{Nu}$ straks skal jeg til middag hos Tillisch, så må jeg træffe en definitiv afgørelse.

I går har 184 ansete borgere $\mathrm{i}$ en formelig revolutionær og truende petition forlangt af landsstyrelsen, at Schrader med samt hans politi straks skal jages bort; Hr. Tillisch har vist mig petitionen; ellers er der ingen, der foreløbig kender den.“

Slaget faldt omgående, og det faldt hårdt:

Allerede 5. januar tilskrev landsstyrelsen die Oberpolizeibehörde: $\left.:^{9}\right)$

På grund af de tilfælde af tumult, der havde fundet sted 2. januar, bemyndigedes politiet til at bringe de af politiet foreslåede forholdsregler til udførelse:

Rektor Lübker, Möller Manne Jürgensen og doktor Diederichsen skal politiet stævne til sig og meddele, at de - om de vil undgå arrestation — har at forlade byen inden 12 timer. - De nødvendige foranstaltninger skal træffes til forbud mod Gewerbeverein (en nyoprettet patriotisk forening, hvis formål var at virke for det tyske fædreland uden hensyn til stand og parti). - Tillige gør man opmærksom på, hvor absolut nødvendigt det er, at politiet bliver instrueret om fuldstændig upartisk at håndhæve deres myndighed, særlig at forebygge enhver fredsforstyrrende sammenløben i gaderne og navnlig ophidsende sange.

8) Rigsarkivet.

v) Landesarchiv. Schleswig Holstein. Gottorp (Registratur A. 1850 der Landesverhaltung). 
Endelig overlader landsstyrelsen det til den overste politimyndighed at træffe aftale med militæret om de sikkerhedsforanstaltninger, der vil være at træffe.

Dette skete netop på en tid, hvor ophidselsen vel var på sit højdepunkt: 17. januar; få dage senere, udløb våbenstilstanden, og det hed sig, at der den dag vilde ske noget afgørende. Fra mange sider modtog Tillisch meddelelser snart om krigerisk indbrud i Slesvig, snart om en overrumpling af Flensborg, snart om et morderisk attentat på politimester Schrader. Det hed sig, at der forsøgtes natlige overfald på loyaltsindede borgere, og værkmester Kruse fandt det rådeligst at forlade staden. ${ }^{10}$ )

I dennne ophedede atmosfære var det altså, at udvisningen af rektor og de to andre tyskere skete.

Alle primanerne (undtagen een) demonstrerede ved at udeblive fra skolen, de følte sig solidarisk med deres rektor. - En stor kreds af borgere rettede $i$ heftige ord opfordring til magistraten om at bruge sin indflydelse, og magistraten androg indtrængende, „dass der Rector Doctor Lübker dieser Schule baldigst wieder gegeben werden möge." (25. januar).

Mest indtrængende var dog det andragende samtlige 7 lærere indsendte til landsstyrelsen for hertugdømmet Slesvig (19. januar 1850). Efter s.tilen at demme er det sikkert konciperet af Schumacher $!^{11}$ )

Vi undertegnede er ved den fra oven foranledigede fjernelse af vor kollega og rektor, dr. Lübker, blevet ramt på det smerteligste og føler os $\mathrm{i}$ vor samvittighed tvunget til åbent at udtale denne vor følelse for landsstyrelsen. - Hvis det vel $\mathrm{i} \mathrm{og}$ for sig er en hård tilskikkelse, når pludselig og for længere tid en skoleleder bliver taget fra skolen, så kan der i det foreliggende tilfælde ikke være mindste tvivl om, at der vil blive tilføjet vor skole en uoprettelig skade, hvis vor rektor i længere tid bliver udelukket. Ingen er $\mathrm{i}$ den grad som vi i stand til at vide,

10) Sønderj. årb. 1900 s. 135.

11) (Fr. Lübke:) Die Kirche u. Schule im Kampfe mit der sogenannten Landesverwaltung. Kiel 1850. 
hvilken skat $\mathrm{i}$ alle dele Gud har givet vor skole i denne mand. - Hans store lærdom, hans rige ånd, hans monstergyldige orden og praktiske sans, hans hjertegribende læreevne og fængslende veltalenhed, hans fuldstændige overblik over alt, hvad der båder skolen i stort og småt, alt det har blandt os og blandt hans elever stået sin prøve på mangfoldig måde og til velsignelse, men, hvad der er mere til ære for ham og glæder os, lærere som skoledrenge, endnu mere end hin høje begavelse, det er hans sandhedsøgende, kærlige sind, det ærekære ved hans karakter, det er den sjældne, alle modsætninger forsonende elskværdighed, hvorved han har vidst at vinde og beholde vort hjerte og vor fulde tillid; han har, $i$ al den tid han var hos os, $i$ sindelag, ord og gerning lyst som et forbillede for os alle; - ved ham har skolen på kort tid fået et herligt opsving, som den måske aldrig har haft tidligere på en så levende, hjærtet glædende og fredfyldt måde.

Denne mand, denne leder og hjælper i vort arbejde med vor dyrebare ungdom, denne os alle så nærstående ven, er nu ved en skæbnesvanger afgørelse blevet revet fra os, og vi må højlydt bevidne, at så længe vi mangler ham, mangler vor skole og vort arbejde det glade mod og den åndens løftelse, som hidtil har fyldt os ligesom ham og været så ubeskrivelig velgørende. Lige til den stund, da rektor Lübker er givet tilbage til sin skole, lige til denne skole er givet tilbage til sin elskede rektor, er og bliver kraften ved denne læreanstalt, der er så vigtig for Flensborg og hele dens udstrakte opland, brudt. Det knusende slag er kommet over vor skole, uden at det har været os muligt at se den mindste sammenhæng mellem årsag og virkning; tværtimod, vi er overbeviste om, at, hvis det var kommet til en undersøgelse i sin fulde udstrækning - som vi havde ventet det - af hvad der var sket, så var det ikke kommet til denne forholdsregel.

Vi for vor del kan kun slutte dette vort hjærtes og vor samvittigheds vidnesbyrd med det inderlige ønske og $\mathrm{i}$ det håb, at 
dette må give stedet til, at det for vor kollega og ven igen bliver muligt at være en velsignelse for os og vor skole. ${ }^{12}$ )

Ved en skrivelse samme dag (19. januar) gav 50 forældre, d. v. s. omtrent samtlige hjem, deres tilslutning og ønskede, at dr. Lübker, der „ein grosser Segen für unsere Schule und für unsere Kirche ist“", så snart det på nogen måde var muligt, skulde vende tilbage til sin virksomhed.

I disse skrivelser er tonen naturligvis afdæmpet, men hvor forbitret stemningen var, fremgår af et opråb fra gymnasielærerne i Altona og Glückstadt.

„Underskrevne lærerkollegier, oprørt over den forsmædelige og uhørte behandling, der er overgået deres kollega, den højtfortjente dr. Lübker i Flensborg, ... føler, det er deres pligt offentlig at udtale deres dybe modvilje mod en sådan fremgangsmåde, der forhåner al ret og anstændighed, og som kun er tænkelig for et politiregimente, der er afstumpet mod at lytte til retten. $\mathrm{Vi}$ opfordrer alle lærere $\mathrm{i}$ vort hårdt betrængte land til: fast og frygtlest også i fremtiden at stå på Slesvig-Holstens gode ret, og at opdrage deres disciple således, at den yngre slægt med samme iver og mod må forsvare vore umistelige rettigheder."

Men naturligvis gjorde hverken dette eller hint indtryk på styrelsen.

Da nogle dage var gået, rejste Lübker og Möller Jürgensen til Berlin for at fremføre deres Klage for den prøjsiske konge, Frederik Wilhelm IV.

23. januar fik de foretræde og gav majestæten en skildring af de frygtelige tilstande, der lader hånt om al moral.

Kongen lånte dem villigt og opmærksomt øre, fortæller Lübker.

Men reaktionen havde jo nu sejret i Berlin.

7. februar modtog de en skrivelse fra kongens kabinet, hvori

12) I disse dage udgav en af skolens lærere, dr. Gidionsen en tale Von der Bildung, han havde holdt dagen for juleferien. Den havde et Nachwort, hvor samme hengivenhed for rektor kommer til orde. 
man tilrådede dem indrømmelser og underkastelser, så de kunde vende tilbage. Men de svarede (17. februar):

Deres Majestæts deltagelse er for ædel til, at den skulde tilråde os at fornægte sandheden, bekende en skyld, som vi ikke har, og ved vor tavshed kaste en plet på tilstande og personer, som efter vor bedste overbevisning ingen bebrejdelse kan ramme - for at vi igen kunde vende tilbage til rolig og uforstyrret nydelse af vore borgerlige rettigheder og vort arbejde.... Vi vil til enhver tid villigt lade vore forhold underkaste en undersogelse af landets domstole, for at den forurettede part kan få fuld oprejsning; men vi vil ikke ved tilståelser, der vilde være af en uren karakter, skaffe os privatfordele, medens det hele land i urokkelig og fast holdning ligger bøjet i dyb sorg, som det må føle over et voldsherredømme, som undergraver landets ret, krænker lovene, bringer den personlige sikkerhed i fare, forhåner kirken, tømmer skolerne og prisgiver ungdommen til demoralisation (Verwilderung). Denne sædelige følelse deler vi med alle vore landsmænd, og vi kan og må ikke ønske, at en følelse, - uden hvilken al velsignelse ved borgerlig orden for stedse vilde gå tabt, — skulde blive neddæmpet eller kvalt, for at vi skulde opnå en selv nok så stor ydre fordel. Hvis landsstyrelsen . . . så umotiveret tør bruge vold og har mod til at retfærdiggøre den med usandfærdige fremstillinger, da vil vi hellere, hvor meget det end piner os, i længere tid se os bandlyst fra hjem og virksomhed, og vi vil også i fremtiden bære uret og vilkårlighed, indtil den lykkelige dag oprinder, der gengiver vort arme land lov og ret, ro og orden.

Endnu håbede dr. Lübker; en stærk slesvig-holstensk hær stod jo ved Isted. Han var i Kiel som medlem af landsforsamlingen og af en af statholderskabet indsat kommission, der skulde udarbejde en undervisningsplan for Slesvig-Holsten.

Men efter nederlaget tog han (1851) mod stillingen som rektor for gymnasiet i Parchim i Mecklenburg, og her i landflygtigheden var han en flittig forfatter af filologiske, pædagogiske og kirkehistoriske arbejder. 
Der skulde gå mange år, før han genså Flensborg og sin skole.

Den loyale konstituerede rektor.

Primanerne erklærede sig solidariske med deres rektor, de vilde ikke komme tilbage, før han kom tilbage. Men da deres skolestrejke havde varet $\mathrm{i}$ omtrent tre uger, var vist de fleste vendt tilbage. I hvert fald meddeler den konstituerede rektor, Schumacher (20. januar 1850), at de indenbys er kommet tilbage. De udenbys opholder sig - so viel uns bekannt - hos deres familie, men brev. er sendt dem om ufortøvet at indfinde sig.

Efterhånden er de vel kommet tilbage. Men den fjendtlige stemning tog ikke af. 17. Maj 1851 måtte overpræsident Lassen skrive følgende brev til det slesvigske ministerium: $:^{13}$ )

Jeg føler mig forpligtet til at meddele Deres Exellence, at den fremherskende ånd hos eleverne .... tager en uansvarlig, dårlig retning. Ved enhver lejlighed lægger nemlig disse unge personer, endog i de lavere klasser, deres slesvig-holstenske sympatier for dagen, forhåner og belér, med en indflydelse, der i forvejen er dem indpodet, alle danske symboler; de har allerede flere gange bragt politiet $\mathbf{i}$ den største fristelse til at skride ind på åben gade med stokken. For godt 8 dage siden blev sønnen af navigationslærer, kaptajn Middelboe, der går i den latinske skole, formelig forhånet og mishandlet på åben gade af sine commilitones, og jeg undlod kun en politi-undersegelse, fordi den konstituerede rektor, Schumacher, afgjorde sagen arbitrært. Samme aften blev to primanere, tager jeg ikke meget fejl, Jensen og Jansen, som havde sunget på gaden, af politibetjente bragt til mig, den sidstnævnte var stærkt beskænket. Det er desværre! ofte sket, at de større elever i offentlige lokaler solder om aftenen, og så i deres udgydelser lader en oprørsk ånd komme frem. Om dette uvæsen skal lægges lærerne eller forældrene til last, skal jeg lade stå hen; men da forskellige klager over elevernes opførsel er kommet mig for ore, og ovenomtalte facta foreligger, holder jeg det for min pligt at underrette Deres Exellence derom.

13) Rigsarkivet. 
I anledning af denne klage sendte Schumacher (20. maj 1851) følgende erklæring:

Han protesterer mod at skolens ånd havde taget „en uforsvarlig retning." Flid, orden, opmærksomhed, samdrægtighed, lydighed mod lærerne måtte disciplene roses for. Når skolens ånd kaldes vorherrschend schlecht, så kan meningen kun være politisk. Hvorledes i politisk henseende den enkelte elev er sindet, hvor vidt han, ved sin opdragelse hjemme, har bestemt sig til at tage parti, det unddrager sig, efter sagens natur, næsten fuldstændig skolens kendskab. Skolen som sådan kan og skal holde sig borte fra politisk liv, kun bekymre sig om disciplenes videnskabelige og religiøse opdragelse.

„Når der dog tales om en politisk dadelværdig ånd $\mathrm{i}$ vor skole, så må jeg fremhæve som . . . kendsgerning, at i skolen og for lcerernes øjne bliver en sådan ånd holdt fuldstændig hemmelig, og jeg tør vel tilføje som begrundet formodning, at kun enkelte af vore elever, slet ikke dem alle, har gjort sig skyldig i strafværdigt overmod $m$. h. t. deres politiske sympatier.

I forhånelsen og mishandlingen af den danske dreng Middelboe, lå der ikke, hævder Schumacher, nogen politisk tendens. Drengene har fået deres straf.

Sekundanerne havde holdt deres „Fuchscommerz“. Jansen og Jensen vil, efter skærpet straf, blive sat ned i klassen. De havde været berusede. -

Der er næppe nogen tvivl om, at overpræsidentens skildring af de forbitrede følelser hos de tyske drenge er rigtig. Når man ikke vilde indrømme det fra skolens side, kan grunden være den, at lærerkollegiet selv nærede de samme følelser; man har sikkert, med sympati for drengene, fulgt den lille krig. - Schumacher som skolens leder måtte prøve at balancere.

I en piece fra denne tid (1850) "Characteristik af de mænd, der i byen Flensborg har vist sig som revolutionens håndlangere .... ved en stille iagttager" hedder det:

„Lübker, Jessen og Momsen på latinskolen udmærker sig ved tordnende casinotaler, der have forvildet manges hjerne, så de begik de værste udskejelser. .. . Skønt skolens øvrige læ- 
rere, Schumacher, Dittmann; Kühlbrand og Gidionsen, ikke have sådanne talegaver, så var det dog synd at sige, at de ikke gjorde deres pligt som rebeller. I hver time bevise de sig som oprørets nidkære tjenere. Deres brave drenge levere derfor det bedste bevis, idet de udskælde dansksindede, spytte på jorden ved at se dem og bevise dem slige høfligheder. I deres fritimer endog opmuntre deres lærere dem dertil, ved at tilråbe dem gennem det åbne vindue: "Bliver kun ved, drenge, det skal nok hjælpe."

Om en af drengene, en søn af advokat Johannsen, hedder det: „Som ægte jæger efter rød-hvidt kigger han gennem folks vinduer, og ser han nu gardiner eller bånd af samme farve, så Gud nåde folkene, om evnen er som villien. $\mathrm{Nu}$ må han rigtignok nøjes med at skære grimasser med hans abefjæs og smøre haser, når han kan frygte for at blive forfulgt; for andetsteds at begynde forfra. Gadelapsen tænker vistnok med glæde tilbage på det Crohn'ske regimente, da han turde gøre alt, hvad han vilde, ja han siges endog at have skudt på folk $\mathrm{i}$ de sidste dage af august $f$. a."

Det er et fanatisk skrift, og enkeltheder står ikke til troende (Schumachers optræden er fantastisk!), men det giver sikkert et godt billede af ophidselsen mellem ungdommen på tysk side; særlig ved rektor Lübkers drenge.

Ved denne tid var det også, at stenhugger H. A. Kleewing lod offentlig bekendtgøre, at han for fremtiden vilde tage sig selv tilrette over for de uvorne latinskoledrenge, der forhånede og overspyttede ham på offentlig gade..$^{14}$ )

I sommerferien 1850 forlod Mommsen (født i Oldesloe) skolen og rejste sydpå, og noget senere måtte Gidionsen (født i Svansen), der havde været frivillig i den slesvig-holstenske hær, opgive sin stilling i Flensborg. De var — som Lübker - blevet ansat af den provisoriske regering.

Christian Peter Jessen (født i Kværs ved Åbenrå) derimod havde været lærer ved skolen siden 1846. 2. oktober 1851 af-

14) P. Lauridsen: Mellem Slagene. 1849-50. (Sønderj. årb. 1900 S. 147)) 
skedigedes også han; den ydre foranledning var, at han på en rejse i Tyskland havde indskrevet sig som "aus Nordalbingien.“

14. oktober 1851 skriver han til kongen ${ }^{15}$ ):

Som et tordenslag traf mig meddelelsen om, at K. M. har besluttet at afskedige mig fra mit embede - en skæbne, hvis bitterhed for mig er blevet end pinligere ved, at jeg i offentlige blade måtte læse det, 5 dage før jeg fik officiel meddelelse derom; det var mig så meget hårdere, som jeg over et år ærligt og tro har forvaltet mit embede under den nuværende øvrighed. Ganske vist er der for nogle uger siden blevet affordret mig en erklæring på tro og love om to punkter, men at en ferierejse til udlandet eller en spøgefuld, formløs betegnelse af min hjemstavn med navnet Nordalbingien på et ganske irrelevant sted skulde være en sådan forseelse, at den vilde få en afskedigelse til følge, kunde jeg ikke formode.

Jeg kan derfor ikke lade være med at søge grundene til min afskedigelse andetsteds. Og dog, ser jeg tilbage på min virksomhed, så finder jeg den ikke der. 14 år har jeg virket som lærer $\mathrm{i}$ offentlige skoler, $6^{1 / 2}$ her som collaborator, og stedse har mine foresatte givet de mest anbefalende vidnesbyrd om samvittighedfuld pligttroskab og videnskabelige evner. Al min kraft har jeg brugt til mit embede, har også i tider af den højeste ophidselse stræbt at holde eleverne indenfor kredsen af deres opgaver og videnskaben og alt fremmedartet borte fra skolen, og, da flere lærere blev fjernet, af alle kræfter at udfylde hullerne, så at jeg i $3 / 4$ år har været hovedlærer for de to øverste klasser. Og derfor er der aldrig blevet mig nogen gunst eller fordel (Bevorzugung) til del ....

Men heller ikke i mit liv ellers formår jeg at opdage nogen så svær skyld. Jeg ved mig fri for enhver plet på karakteren (sittlicher Makel). Ganske vist, $\mathrm{i}$ en anden retning, men hvor få kan dér påstå i de sidste år at være fri for enhver sørgelig forvikling? Men min underordnede stilling bragte mig næsten ikke $\mathrm{i}$ berøring med de mangfoldige sørgelige forviklinger i det offentlige liv, tillod mig derimod at indskrænke mig til den

15) Akten d. sch. Min. von Gelehrt. Schule in Flensburg. Kiel. 
snævre kreds, mit hjem og min skole, således som det stedse har passet for min måske for indesluttede og tilbageholdende karakter .... Jeg har altid holdt mig borte fra enhver offentlig og politisk virksomhed, har altid beflittet mig på mådehold og har stræbt, efter mine svage kræfter, at bekæmpe yderligheder, som trådte mig i møde i min kreds.

Jeg tør derfor nære det håb, at min afskedigelse ikke er en straf for tidligere skyld, men har sin grund $i$, at min måde at lære på og min didaktiske virksomhed ikke passer til den herværende skole, som man ønsker den i fremtiden, og at derfor min videre virksomhed ikke vil være fremmende for det, man fra nu af har som mål."

Men det slesvigske ministerium kan ikke godtage hans fremstilling. I allerunderdanigst forestilling af 8 . november s. a. hedder det:

.... Det vidnesbyrd, han således har givet sig selv, stred imidlertid for meget imod, hvad der angående hans adfærd var almindelig bekendt, at det ansås nødvendigt at anmode Flensborgs overpoliti om at indhente nærmere oplysning desangående. Af den i den anledning anstillede løselige undersøgelse fremgår der nu, at dr. Jessen 1848 har anlagt den tyske kokarde og har vist sig dermed i selskab af skoledisciple, hvilket sidste dog, efter hans forklaring, kun skulde være sket tilfældigt; at han har været medlem af den såkaldte tyske Casino-klub .... og har deltaget $\mathrm{i}$ forskellige fra denne udgåede politiske demonstrationer, for eksempel et fakkeltog, som blev bragt general Bonin i foråret 1849, eller flere adresser, som i efteråret $1848 \mathrm{og}$ i foråret $1849 \mathrm{blev}$ sendte den tyske nationalforsamling i Frankfurt, .... at han ligeledes har tiltrådt den erklæring, som superintendent Nielsen ${ }^{16}$ ) med adskillige gejstlige lod udgå for at lægge grunden til den såkaldte passive modstand mod Bestyrelses-commissionen, samt at han, ligeledes i begyndelsen af 1850, har underskrevet den truende adresse, ved hvilken en del af Flensborgs beboere vilde nøde Bestyrelses-commissionen til at bortfjerne etatsråd Schrader fra byen.

16) Slesvig-holstenernes biskop i Slesvig. 
Disse eksempler, som uden tvivl ved en nøjere undersøgelse let vilde kunne forøges, turde være mere end tilstrækkelige for at vise, at dr. Jessen, langt fra at udmærke sig ved .. mandighed, har hørt til de politiske agitatorer, som i årene 1848 og 1849 tilrev sig herredømmet i Flensborg og undertrykkede byens besindige og loyale borgerstand.

(Han afskedigedes med pension).

Af tyske lærere fra tiden før 1848 var der nu i 1851 følgende tilbage: den ubetydelige Dittmann (født i Münsterdorf) og den dygtige seminarist Schnack (født i Frederiksstad) og den udygtige seminarist Kühlbrandt (født i Neumünster). Samt C. F. Schumacher (født i Husum 1799), der jo var blevet konstitueret som rektor, da Lübker var blevet forvist.

Medens vi i Lübker har den fanatiske slesvigholstener og i Jessen den mere forsigtige og afdæmpede slesvigholstener, har vi i Schumacher en tredie type.

25. februar 1852 skrev han til Regenburg( ${ }^{17}$ ): „Jeg har ifølge mine forhold ved fødsel og opdragelse, efter mine fra ungdommen nærede sympatier, ifølge min samvittighed, som finder sin rettesnor i Guds ord (Romerbrevet 13. og 1 . Peters brev 2) ${ }^{18}$ ), stedse med glæde været en dansk statsborger og siden 1828 kongelig dansk embedsmand.

Den hele tordensvangre forberedelsestid for den usalige partidannelse i hertugdømmerne har i sin egentlige karakter været som tilhyllet for mine øjne. De utilfredse partimænd ignorerede eller skyede mig som uindviet; til mig, der levede stille $i$ mit hus, min skole og min videnskab, kom fra ingen side en indbydelse for eller et forsøg på at vinde mig; jeg var naiv (harmlos), tilfreds og samtidig troskyldig (arglos) for den kommende ulykke.

Som et lyn fra klar himmel kom for mig katastrofen den 24 . marts 1848; jeg havde ikke haft en anelse om muligheden af et

17) Regensburgs brevsamling. Rigsarkivet.

18) Hver sjæl være de høje фvrigheder underdanig, thi der er ingen $\phi v r i g h e d$ uden af Gud. - Erer alle, elsker broderskabet, frygter Gud, ærer kongen. Tjenere være i al frygt deres herrer underdanige. 
sådant udbrud. Jeg var højst uhyggelig til mode. Den kongelige embedsmands samvittighed blev ved "den provisoriske regerings" selvbestaltning uhyggeligt foruroliget; jeg takkede Gud for, at jeg ikke kom i nogen berøring med denne faktiske øvrighed.

Allerede ved enden af 1847 havde det forlydt, at man påtænkte en omdannelse af de lærde skoler i hertugdømmerne; ved den vakance $\mathrm{i}$ konrektoratet ved Slesvig domskole, der derved var at vente, kunde det kun være mit ønske at ombytte det af mig siden 1831 beklædte subrektorat med hin stilling. Jeg udtalte lejlighedsvis dette mit ønske for medlemmer af den daværende slesvig-holstenske regering, uden at nogen afgørende bestemmelse kunde træffes. 28. januar 1848 kom det nye regulativ for vor skole; min forhåbning om den håbede forbedring blev så meget mere levende. Da kom afbrydelsen af hele den bestående orden.

Siden gjorde jeg intet skridt i min sag; jeg tav og ventede. Ganske uventet kom 26. august 1848 etatsråd Nitzsch ${ }^{19}$ ) hen i mit hus med det direkte spørgsmål: „Om jeg var villig til at overtage konrektoratet vєd Flensborg lærde skole; regeringen onskede denne min forflyttelse og mente, at min personlige virksomhed vilde være fordelagtigst netop ved denne skole.

Jeg var fuldstændig uforberedt; jeg kendte næppe Flensborg, den daværende skole slet ikke; hvad skulde jeg gøre? Hvad skulde jeg navnlig gøre med den eventualitet for øje, at måtte lade mig udstede et senere hen ugyldigt ansættelsesbrev? Fremtiden lå mørk for mine øjne. Den offentlig fremsatte påstand om „H. M. Kongens ufrihed" fik mig til at finde det umuligt nu at opnå en lovmæssig bestalling: enhver faktisk embedsforandring i hertugdømmerne dengang havde efter min overbevisning til forudsætning, at efter den foreløbige bestalling vilde H. M. Kongens lovlige bekræftelse følge. I denne følelse, i denne forventning, dette håb — da jeg vidste mig min

19) Gregers Wilhelm Nitzsch, tysk filolog, professor i Kiel. «Undervisningsinspekt $\varnothing \mathrm{r} \propto$ for hertugdømmerne. 
konge tro i langvarig tjeneste indadtil som udadtil - troede jeg at måtte modtage den mig tilbudte stilling.

To grunde trådte til, en speciel, pligtfølelsen: Alle mine søskendes stilling var en sådan, at jeg kunde gå ud fra, at en meget stor del af forsørgelsen af de hjælpeløse søstre måtte falde på $m i g$ efter min gamle faders ${ }^{20}$ ) død; en forøgelse af mine indkomster var derfor højlig nødvendig. Den anden grund var af almen art: Ved udsigten til at komme til Flensborg havde jeg den ejendommelig-behagelige følelse, at jeg så boede $5 \mathrm{mil}$ nordligere. Den krampagtig voldsomme ånd i hele syden $\mathrm{i}$ almindelighed og i byen Slesvig i særdeleshed var mit inderste væsen helt fremmed for; jeg længtes efter et mere roligt hjem, og dette, syntes jeg, vinkede i Flensborg.

Regeringens anmodning var blevet stillet mig fuldstændig uden min foranledning; jeg har hverken før eller siden føjet en skriftlig eller mundtlig bøn til: det hele var mig som en kalden (Ruf) fra Gud, som en "trosprøve“. I "tro" har jeg begivet mig til Flensborg og har arbejdet i stille opfyldelse af min pligt; i denne hengivne "tro" har jeg til nu fundet min ro, når mit blik ud $\mathrm{i}$ fremtiden undertiden var ved at formørkes.

Fra den dag, da den kongelige myndighed i den kongelige regerings-kommissær var kommet tilbage, følte jeg mig befriet fra en tung byrde. Ikke tvunget af omstændighederne, men ud fra min samvittigheds frieste tilslutning stod jeg nu igen uforstyrret under min lovmæssige øvrighed.

Efter at jeg således - bort fra al omskiftelse og bort fra usikkerheden i min politiske bevidsthed, der undertiden kom over mig i begivenhedernes stormløb - havde genfundet min gamle ro og netop derfor havde fået bekræftelse på en offentlig stilling af betydning, har mange bebrejdelser fra tidligere venner truffet mig. Jeg har deri kun set et offer, der ofte gjorde

20) Georg Friedrich Schumacher, født i Altona 1771. 1820-35 rektor ved Slesvig domskole. Forfatt. af Genrebilder aus dem Leben eines 70jährigen Schulmannes ernsten $u$. humoristischen Inhaltes. Han døde 1852. 
meget ondt, men som jeg havde pligt til at bringe min samvittighed."

Nogen taktik er der vel nok i dette brev. Men det er sikkert rigtigt at karakterisere Schumacher som den loyale, kongetro slesviger, en forsigtig mand, uden en alt for stærk overbevisning. Hans stilling som slesvigernes førstemand på skolen senere hen mellem de mange kongerigske kolleger har ikke været let, og han har sikkert befundet sig bedst mellem sine slesvigholstenske kolleger, som han havde uddannelse og hjemstavn fælles med.

Den danske skole. Rektoren fra Kongeriget.

August 1849 var Tillisch kommet til Flensborg som Danmarks repræsentant $i$ bestyrelseskommissionen. Med ham fulgte som hans sekretær $A$. Regenburg.

Regenburg så mørkt på situationen, som den var for øjeblikket $\left.{ }^{21}\right)$ :

„Dette ophold ${ }^{22}$ ) er tilvisse ikke noget glædeligt. Man ser Slesvigs og Danmarks skæbne stå på spil, man ser, at intet eller lidet gøres og kan gøres for at sikre et heldigt udfald, og man gennemtrænges af en følelse beslægtet med den, man vilde føle, når man fra strandbredden så sin broder $i$ fare for at drukne og ikke kunde hjælpe ham, men måtte overlade hans frelse til tilfældet, eller jeg vil hellere sige Forsynet; thi at Forsynet endnu må vende tingene til fordel for Danmark, er et håb, jeg ikke kan opgive, hvor morkt det her end ser ud. De mennesker, hvis demoralisation i deres værk så klart er bragt for dagens lys, ere endnu i besiddelse af hele embedsmagten i hertugdømmet, de udspinde endnu, skønt så godt som åbenlyst, ustraffet deres intrigers net over landet." (Flensborg 6. sept. 1849).

1. september 1850 blev denne ivrige mand departementschef i det slesvigske ministerium.

21) Danske Magazin 7 R IV 256.

22) I Flensborg. 
Mellem de vanskelige opgaver, han fik, var også den at reorganisere det højere skolevæsen i hertugdømmet.

I Haderslev blev det en dansk skole med dansk undervisningssprog, i Slesvig en dansk skole med tysk undervisningssprog.

Mere broget lå forholdene i Flensborg.

Til rektor her kaldtes 2 . juli $1851 R$. J. Simesen.

Han havde studeret ved Polyteknisk Læreanstalt og været amanuensis ved $\mathrm{H}$. C. Ørsted. Efter at have taget polyteknisk eksamen blev han af det schleswig-holsteinske patriotiske selskab i Altona ansat til at holde foredrag over matematik og fysik for håndværkere og teknikere. Dermed forbandt han skoleundervisning i gymnasiet. Her var han 4 år. 1843 sattes han til at organisere og bestyre den nye videnskabelige realskole $\mathbf{i}$ Helsingør.

Flensburg Gelehrtenschule omdannedes til Flensborg Lærde og Real-Skole. Der havde i borgerstanden i byen i de sidste 10-15 år været stærke ønsker om undervisning i realfagene; nu blev de altså imødekommet.

Men det, der her har interesse, er, hvorledes skolen indrettedes nationalt.

Man valgte at gøre Flensborg skole til en skole med to undervisningssprog, et forsag, der vist ellers intetsteds er forsøgt; dansk og tysk var sideordnede.

Det var svært at få gennemført. Da der var gået et år, skrev rektor Simesen i programmet (sept. 1852): „Den påbudne ligeberettigelse af sprogene har hidtil ikke kunnet strækkes videre end dertil, at, foruden den egentlige undervisning $i$ dansk, først fædrelandets historie, ${ }^{23}$ ) og siden også verdenshisto-

23) Om Danmarkshistorie i skolen fortæller rektor i 1852: „Undervisning i fædrelandshistorie måtte aldeles pảbegyndes efter Allens lærebog, da der hidtil var læst Danmarks historie efter: Dielitz's Leitfaden in der Weltgeschichte, der ikke meddelte stort andet om det stakkels Danmark, end at det ved krigen med England er berovet sin velstand, at den udenrigs handel er ubetydelig, den indenlandske ringe p. gr. af slette veje, og industrien utilstrækkelig; - et for danske (om også tysktalende) drenge lidet glædeligt billede af deres fædreland. 
rie er bleven meddelt på dansk, ligesom også et par danske lærebøger i matematik og physik ere benyttede, imedens dog endnu undervisningen selv i disse fag har fundet sted på tysk. Regnes hertil endnu engelsk, der $i$ den sidste tid $i$ een klasse tildels er bleven oversat på dansk, så have i det sidste halvår af de 248 ugentlige undervisningstimer .... kun de 40 eller næppe en sjettedel kunnet gives på dansk; de 208 er derimod givne på tysk".

C. F. Monrad, ${ }^{23 *}$ ) læreren i dansk og historie, havde 4. april 1852 skrevet til Regenburg, hans skolekammerat fra Sorø: „Det resultat, vor tilendebragte examen har givet, er af den beskaffenhed, at jeg føler trang til at sige dig nogle ord derom, fordi det nødvendigvis må styrke dig ligeoverfor de angreb, hvorfor skolen naturligvis fremdeles vil blive genstand. Når de danske lærere $i$ det hele eller enkeltvis herefter bliver genstand for klage, kan du ganske rolig svare klageren: „Gå til skolen, vær tilstede ved en examen, døm selv om, hvorvidt det danske lærerpersonale er istand til at løse sin opgave, anstil navnlig en sammenligning mellem de danske og de tyske læreres præstationer og kom så igen til mig." Jeg er overbevist om, at selv den mest partiske dommer skulde betænke sig to gange, inden han lod dommen falde til vor skade .... Det vil glæde dig at høre, at det $\mathrm{i}$ dansk og dansk historie gik meget godt. De bedste karakterer faldt i disse fag; i 4 . realklasse fortalte alle drengene deres historie på dansk, de 4 særdeles godt, de 3 simpelt; der hørtes dog næppe ti tyske ord under den hele examination, og efter denne ytrede Schumacher i en eller 2 tyske læreres nærværelse, at han måtte tilstå, det havde undret ham både at høre disse disciple fortælle og navnlig at se, at de helt igennem kunne følge og forstå mine spørgsmål. I 2. realklasse fik af 10 drenge de to ug, $3 \mathrm{ug} \div-, 3 \mathrm{mg} \div$, en $\operatorname{tg}$ og en mdl. ... at jeg ikke, ved hvad jeg her har sagt om mine egne fag, vil stille mig frem blandt mine kolleger, behøver jeg næppe at sige dig, det vilde være meget værre end ubeskedent; men at jeg glæder mig over

2**) Kollaborator C. Monrad (1815-1889), se min afh. Sønderj. årb. 1847 , s. $102 \mathrm{ff}$. 
en heldig begyndelse, og at den giver mig et frejdigt håb om en fremtid, hvori vi uden al foragtelig sammenligning og skinsyge skulde arbejde enigt sammen, det er naturligt."

I løbet af det andet skoleår mener rektor Simesen at være kommen til en rimelig fordeling. På dansk skal der undervises $\mathbf{i}$ følgende fag: dansk, fædrelandshistorie, verdenshistorie samt geometri, kemi og sang (143 timer); på tysk i tysk, græsk, hebraisk, aritmetik, naturhistorie og gymnastik (145 timer), blandet skal sproget være i latin, fransk, engelsk, geometri, fysik, regning, skrivning, tegning.

I religion stod valget hjemmet frit, om hjemmet onskede dansk eller tysk.

I 1859 gør rektor fordelingen op, som den har været sidste skoleår. Skolen består på dette tidspunkt af fire fællesklasser (fra c. 6 år) og derover 3 realklasser (til c. 16 år) og 5 latinklasser (til c. 18 år).

I fællesklasserne har 37 valgt dansk, 142 tysk; i realklassen 8 dansk og 35 tysk. Noget anderledes stiller forholdet sig i de studerende klasser, her har 34 hjem valgt dansk og 26 tysk. De, der har valgt dansk, kommer overvejende fra embeds- og bestillingsmandshjem (i de studerende klasser godt $2 / 3$, i de andre 1/2). Så at sige alle fra Flensborg by har valgt tysk.

At slutte fra valget af tysk til tysk sindelag, vilde være for dristigt, særlig for flensborgeres vedkommende. Derimod kan man sikkert gå ud fra, at de, der har valgt dansk, kommer fra danske hjem.

I skoleåret 1849—50, Lübkers sidste år, var elevtallet kommet op på 95, hvoraf 14 i I, 13 i II og 21 i III. I den urolige tid derefter sank det til 79 (i de 3 øverste klasser $8-8-18$ ), 1 1851, da Simesen overtog skolen. I skoleåret $1851-52$ gik 6 utilfredse ud til skoler i Holsten, 11 "til andre skoler", vel i Flensborg, een til huslærer på landet, og een „forlod byen med sin fader". I Prima var der i 1852 kun 3 elever, i Sekunda 4 og i Tertia 2.

Derpå begyndte elevtallet at stige.

Hidtil havde så at sige alle, der studerede, søgt til Kiel, og 
skoleåret afsluttedes - i overensstemmelse med Kiel - ved påsken og ved mikkelsdag. $\mathrm{Nu}, 22$. november 1851 , blev det bestemt, at studenter fra de slesvigske skoler havde adgang til Københavns universitet uden særlig prøve, og 23 . juli 1852 bestemtes det, at skoleåret skulde være som ved kongerigets skoler, fra 23. august til 23. juli.

Følgen var, at strømmen vendte sig: før havde alle studenter søgt til Kiel, men i årene $1853-62$ søgte 29 studenter fra Flensborg til København og kun 10 til Kiel (eller et andet tysk universitet). Den ånd, der nu herskede i skolen, har vel også bidraget sit dertil.

Da skolen i 1851 fik en dansk rektor, var der kun tyske lærere: Konrektor Schumacher, subrektor dr. Dittmann, collaborator dr. Jessen, 6.te lærer dr. Gidionsen, 7.de lærer Küllbrandt og 8.de lærer Schnack. Af disse entledigedes som nævnt dr. Jessen hurtigt, og "ganske uforudset“ tilbagegav dr. Gidionsen 20. december til regeringen det ham meddelte constitutorium. De ovrige, der - med undtagelse af Dittmann - var ansat af den provisoriske regering, måtte afgive folgende erklæring til regeringen $i$ København: Det er vort inderlige onske og. vi er alle beredte til, for som nu, at anvende de os af Gud givne kræfter i vort så kært blevne offentlige virkefelt og i overensstemmelse hermed i troskab og som samvittighedsfulde mænd at forblive $i$ vore embeder til velsignelse for den os betroede ungdom.

I efteråret ansattes to lærere fra kongeriget. Ved samme tid søgtes der om fire lærere yderligere, navnlig i dansk, historie og engelsk. Der indkom 59 ansøgninger. Simesen gav følgende indstilling:

Da jo enkelte af fagene, nemlig dansk, engelsk, for en del historie og måske religion, ville blive at undervise på dansk, så er det på den ene side nødvendigt, at de lærere, der skulle kunne komme i betragtning, ere det danske sprog fuldkommen mægtige, så meget mere som der kan være rimelig udsigt til, at flere aldeles dansktalende børn efterhånden ville komme til at nyde undervisning, i det mindste i skolens realklasse. På den 
anden side vilde, selv om undervisningen i alle de nævnte fag skulde meddeles på dansk, forholdene dog gøre det umuligt på eengang at nå hen hertil, uden at der i flere discipliner vilde ske betydelig tilbagegang, sålænge indtil alle have erhvervet tilstrækkelig færdighed i det danske sprog; men undervisningen må, selv i fag, for hvilke undervisningen skal være dansk ...., endnu i længere tid for største delen gives på tysk. Det er derfor lige så nødvendigt, at de nye lærere alle må være det tyske sprog mægtige, at de uden væsentlige anstød kunne undervise på tysk. Der tør vel således for det første intet hensyn tages til de ansøgere, der 1) slet ikke have godtgjort at kunne dansk eller 2) kuns kunne det således, at disciplene ved deres undervisning snarere ville have skade end gavn og bestyrkelse m. $h$. $t$. øre og sans for det danske sprog, eller endelig 3) ikke have omtalt eller godtgjort at besidde øvelse $\mathrm{i}$ at udtrykke sig på tysk. (Ved 1) og 2) udelukkes 10, ved 3) 17).

Et andet hensyn, der vistnok for disse pladsers vedkommende bør tages, er, om ansøgerne have studeret eller ikke. Thi vel må jeg indrømme, at man ofte iblandt seminaristerne finder lærere, der $m$. h. t. evnen til at undervise mindre børn ved at træde nærmere til deres standpunkt, langt vilde være at foretrække for en nok så studeret lærer, der manglede denne evne; men dog tror jeg, at det $\mathrm{i}$ dette tilfælde ikke vilde være ønskeligt for skolen, om der måtte ansættes nogen seminarist, dels fordi der allerede stå 2 seminarister som lærere her, dels fordi de nye læreres kræfter for største delen ville blive anvendt ved realafdelingen, hvorved det kunde få udseende af, at denne del af undervisningen godt nok kunde besørges af mindre videnskabeligt dannede lærere og var af underordnet betydning. (6 seminarister udgår).

Til heldigen at gennemføre den vanskelige opgave at bringe undervisningen på god fod i en skole, hvor flid og opmarksomhed høre til sjaldenhederne, disciplinen er slap og allehånde 
uheldige påvirkninger uden fra ere hyppige, $\left.{ }^{24}\right)$ hører imidlertid ikke alene videnskabelig dannede lærere, der er begge sprog mægtige, men skolen ville aldeles ikke kunne fremhjælpes og trives, selv ikke under sådanne læreres virksomhed, når de selv savne den stadighed, alvorlighed og for lærerembedet sømmelige levevis, der må gøre dem agtet, endog af deres virksomheds modstandere; eller når de, med iøvrigt gode kundskaber, mangle evne til at tiltvinge sig alle disciplenes opmærksomhed ved opretholdelse af en god disciplin og ved en til disciplenes standpunkt passende livlig og tiltrækkende behandling af undervisningsgenstandene; eller endelig, når de først under vore vanskelige forhold skulle til at uddanne sig som lærere og erhverve sig en undervisningsmetode; thi de lærere, der skulde kunne virke med held, må i forvejen have overvundet de almindelige vanskeligheder ved undervisning i større skoler.

Det turde derfor ikke være tilrådeligt, om nogen ansattes her ved skolen, der enten er vant til at føre et temmelig muntert liv og kun betragtede undervisningen som et for udkommet nødvendigt onde, eller der savnede den ejendommelige læredygtighed og den øvelse i at undervise i skolen, der ene kan gøre ham det muligt med sikkerhed, rolighed og conseqvents at gennemføre den ham stillede ingenlunde lette opgave at besejre manges modvillighed uden strenghed, blot ved alvor og indtrængende undervisning. (7 udgår. Der er nu 19 tilbage).

Af fagene ... indtager dansk vistnok for tiden og under de ejendommelige forhold her i Flensborg den vigtigste plads og fordrer den dygtigste lærer. Der er intet fag så vanskeligt at give en rigtig god, fyldig undervisning $i$, som netop modersmålet, især når det i st. f. latin skal tjene til grundlag for den almindelige grammatik og for sprogdannelsen overhovedet, og endnu større bliver vanskeligheden, når dette sprog på eengang er modersmål for nogle og fremmed, ja måske endog ved påvirkning udefra, ubehageligt for andre.

24) Fremhævet af K. G. 
Han indstiller Monrad til denne plads og Brasch, Engelhardt og Kühnel til de tre andre..$^{25}$ )

Senere på skoleåret ansattes Otto Fibiger som lærer i græsk.

Simesen mener nu, at paritet er opnået ved, at de 5 nyansatte lærere underviser på dansk, de 4 tyske + Fibiger (fra Kobenhavn, han synes ikke at have speciel forbindelse med tysk) på tysk.

Men senere (o: efter 1851) ansattes der ingen tyske lærere. Så at sige alle de lærere, der kom til, var fra kongeriget, sjældent danske slesvigere. I 1863 var der stadig kun de to akademisk uddannede tyske lærere og to seminarister (og en tegnelærer), men 18 danske (foruden rektor). Det må siges, at når pariteten stadig blev hævdet, var det $\mathrm{i}$ virkeligheden kun en formel paritet $\mathrm{i}$ timetal.

Reaktionen mod den danske latin- og realskole kom ikke blot fra tysksindede krese, men også fra dansksindede, eller i hvert fald tilhængere af helstaten, der var tysksprogede.

Således skrev $(2 / 51860)$ byrådsmedlem P. E. Petersen (på tysk): „Til den anskuelse, at helstatens vel kræver, at det danske sprog hos os skal indføres og indprygles, kan jeg aldrig hæve mig. Contrær! Vi var gode danskere med vor tyske tunge, det har vi sandelig bevist i 1848 ! Men vil man ikke mere anerkende os som danske med vort tyske sprog, — godt - så er vi det ikke! Liv og gods kan et ædelt folk ofre for fædrelandet — religion og modersmål aldrig! — Det er sørgeligt, at man er kommet på denne ulyksalige idé, daniseringen af hertugdømmet.

25) Ove Malling Brasch, f. 1823 i Lerup. 1842 student fra Aalborg. 1852-64 adjunkt i Flensbarg. Skrev skolens historie.

Conrad Engelhardt (1825-81). Privatsekretær ved museumsdirekt $\phi \mathbf{r}$ Christian Jürgensen Thomsen. Student 1848. 1851 adjunkt i Flensborg (engelsk og fransk). Ledede udgravningerne i Torsbjerg mose og Nydam mose 1858-63. Søgte i 1864 at redide den værdifulde Flensborgsamling, men forgæves. Foretog senere udgravningerne i Kragehul mose og Vimose på Fyen.

A. M. A. Kühnel (1821-1877) 1840 student fra Randers. 1845 cand. theol. 1851 kollaborator i Flensborg. 1856 forstander for Tønder seminarium. 1867 sognepræst i Hornbæk.

Otto Fibiger (1824-81). Student 1842. Frivillig 1848-49. 1849 filologisk embedseksamen. 1852 lærer i Flensborg. 1858 timelærer ved Metropolitanskolen. 1871 rektor i Horsens. 
Allerede i marts 1853 klagede den loyale $F . N$. Friedrichsen til magistraten over, at det sprog, man talte i Flensborg, blev forsømt, og opfordrede den til at virke for, at der i den højere skole igen blev undervist på tysk. Rektor Simesens anstrengelser, siger han videre, er i åbenbar modstrid med såvel borgernes ønsker som sprogreskriptet. For de dansktalende medborgere kunde man ad anden vej sørge for muligheder for uddannelse. ${ }^{26}$ )

C. F. Monrad råber straks (9. marts) vagt $i$ gevær ved at underrette Regenburg: „Jeg hører af Simesen, at .... Wühlerierne mod skolen på ny begynde, idet Frederiksen o. s. v. have indgivet et andragende til magistraten med opfordring til, at den vil tage sig af skolesagen og gøre skridt til at hævde Flensborgs ret til en udelukkende tysk real- og latinskole."

Flertallet $\mathrm{i}$ byrådet stod - uanset national sympati - på Friedrichsens side, og den dansksindede rådmand P. A. Petersen forlangte, at sagen forhandledes $i$ byråd og magistrat samlet. Men overpræsident Lassen nægtede det, idet han søgte at berolige stemningen med en erklæring fra rektor Simesen, at tallet på de danske og de tyske timer var ens: $144-144$.

Men flertallet $\mathrm{i}$ byrådet beslutter nu at tiltræde Friedrichsens klage, og 18 byrådsmedlemmer underskriver en besværing til ministeriet om de sproglige forhold ved den lærde skole og indsender den.

Atter bliver Regenburg underrettet. 8. april skriver Lassen til ham:

„Skønt jeg på det alvorligste har nægtet sagens behandling og erklæret denne sag de deputerede ganske uvedkommende, har dog circa 14 af vore deputerede borgere i gaar underskrevet en adresse til ministeriet mod den lærde og real-skole .... Jeg beder dig, kære svoger! at benytte denne omstændighed således, at de slyngler kan få dygtigt på hovedet .... En god minoritet har erklæret at ville underskrive en adresse i modsat retning. Sagen er altså med Guds hjælp ikke farlig.

Andragendet afvistes. -

26) Elisabeth Kardel: Die Stadt Flensburg. s. 156. 150. 
I 1860 blev disse klager ført frem i den slesvigske stænderforsamling af den nys nævnte tysksprogede Flensborg-rådmand, der var dansksindet, $P$. A. Petersen ${ }^{27}$ ): administrationen holdt sig ikke, som den burde, de givne sproganordninger for Flensborg efterrettelig. Han onskede intet forandret ved sprogdistrikterne, og dansk var ham personlig lige så kært som tysk, men det engang foreskrevne måtte følges. - Han fremsatte her de gamle flensborgske klagepunkter: Danskens overvægt over tysk i latinskolen, undervisning i fædrelandshistorie på dansk samt nægtelse af tilladelse til tyske privatskoler.

- „Det var en forbandet tale,“ skrev Skau dagen efter, at den var holdt.

Heller ikke dennegang opnåedes der noget.

Der foreligger fra senere tid en samling af de klager, man fra tysk side har fremført mod den danske latin- og realskole: $:^{28}$ ) „Snart beklagede forældrene sig over, at kun tre eller fire af de herrer lærere hilste eleverne på tysk, alle de øvige foretrak dansk og brugte kun det. Særlig satte Simesen sig fordanskningen som mål, uden hensyn til de mange klager og besværinger fra forældrekrese; thi efter hans overbevisning „er Tyskland ikke slesvigerens fædreland, selv om også mangen en fader eller forfader til de indvandrede slesvigere har boet i Tyskland".

Stadig blev der fra forældrene indgivet besværinger til magistraten og til stænderforsamlingen.

Eleverne skulde nu vende blikket mod nord og ophøre med at se mod syd. Således blev det ikke tilladt at gå med klassehuer som kielernes og rendsborgernes; ligeledes blev det dem 1859 nægtet at fejre en Schiller-fest. ${ }^{29}$ ) Overalt blev de sat under opsyn, og $1861 \mathrm{blev}$ endog tre af dem kastet i fængsel, fordi

27) Holger Hjelholt: Den slesv. stænderforsamling i 1860 (Hist. tidsskr. 9. r. III s. 296).

${ }^{28}$ ) Dr. Reinhard Kunkel, Flensborg, i Der Schleswig-Holsteiner. 1941. s. 117.

29) Schiller var født 10. november 1759. 
de efter midnat $\mathrm{i}$ en knejpe havde sagt, at de ikke vilde være danske (das Dänentum abgelehnt hatten)."

Hvor meget disse beskyldninger har på sig, kan ikke siges med sikkerhed. At lærerne, født i kongeriget, ønsker at hilse på drengene med god dag, og ikke med guten Tag, kan dog ikke forbavse; heller ikke, at Simesen har sagt, at Tyskland ikke var slesvigernes fædreland, men at grænsen var Eideren; og når skolen ikke har ønsket, at man fejrede festen for Schiller, „,rihedens" digter, var det vel, fordi man vilde undgå demonstrationer.

Hvem vil iøvrigt mene, at en skole kan blive ledet gennem mange år - uden at der bliver begaaet fejl.

Værre er en episode, der ikke omtales:

8. oktober 1861 indviedes en ny stor skolebygning ${ }^{30}$ ) med taler på tysk og dansk af rektor og biskop.

Til festballet om aftenen var foruden lærerne med damer (60 pers.) og foruden verdslige embedsmænd og håndværkere med damer (63 pers.) indbudt samtlige disciple med disses forældre og hver med en dame (807 pers.).

Så skrives der (i skolens program 1862): „Af skolens 288 disciple manglede ved denne, for alle, der gennemtrængtes af kærlighed til kongen og fædrelandet, så kære fest .. $16(H$. Andersen, brødrene $L$. og $H$. Andersen, brødrene $H$. og P. Korff Petersen, G. Cantieny, brødrene E., M. og A. Marr, N. Boie, brødrene F. og C. Döll, A. Eckeberg, E. Schmidt, E. Franzen og 1. Martens), der ikke erholdt tilladelse af deres forældre til at deltage $i$ festen, ligesom disse heller ikke benyttede den dem tilstillede indbydelse."

Det er en uklog og noget hensynsløs reaktion mod de 11 tyske hjem.

Men i det store og hele kan det vist siges, at årene $1852-63$ i Flensborg lærde skole har været en ret rolig tid efter ophidselses-årene 1848 - 51 .

30) E. B. Svane: L. A. Winstrups vigtigste arbejder: Flensborg latinog realskole (Sønderj. årb. 1946, s. 177-202). 
Hvordan var nu forholdet mellem lærerne indbyrdes og mellem lærere og disciple?

Rektor Simesen var en ordrig og noget omstændelig herre, noget for selvbevidst; han synes at have manglet evnen til at vinde hjerter og være det naturlige samlingsmærke. Måske har også hans specielle uddannelse som polytekniker og interesse isoleret ham noget blandt filologerne. En meget bitter strid havde han med græsklæreren Otto Fibiger, der var kværulant. De skrev til hinanden, skønt de var i samme bygning den halve dag, en korrespondance, der tilsammenlagt er snarere en bog end en piece, og som er ingen af dem til ære, Fibiger mindst (1858 tog han sin afsked fra Flensborg; det lettede!)

Der var flere flinke lærere, og lærerpersonalet var vel m. h. t. dygtighed som ved andre skoler. Men den unge lærer Vilhelm Munck har sikkert ret i sin dom om det $^{31}$ ): „Desværre opdagede jeg snart, at der var liden enhed mellem den lærerstab, som skulde virke i skolen. Rektor magtede ikke den vanskelige opgave at samle de enkelte led til en helhed; skolens mange filologer var ikke fri for at se ned på ham som polytekniker, og hans interesser gik unægtelig også overvejende i naturvidenskabelig retning. Der var lidet samliv mellem de ældre lærere . . og os yngre; lærermøderne var sjældne og kedelige; hver passede sit og lod de andre passe deres."

Der er heller ikke megen glæde i det, gamle Flensborg-drenge har skrevet om deres skole (Thomas Graae: Gamle Minder. 1917. Niels Lassen: Erindringer I 1918. H. M. Fenger: Erindringer fra mit liv 1925)..$^{32}$ )

De tre drenge var kongerigske; men skarpest udtaler en sønderjyde sig, A. D. Jørgensen (En redegørelse, 1901, s. 29): „Læ-

31) Fængselspræsten pastor Vilhelm Muncks oplevelser. Memoirer og breve. XXXVI. s. 56 .

32) Thomas Graae (1849-1920), søn af G. F. A. Graae, præst ved St. Hans kirke i Flensborg. Student 1868 fra Herlufsholm. Journalist. Forfatter.

Niels Lassen (1848-1923), s øn af H. C. L., sognepræst i Adelby. 1865 student fra Metropolitanskolen. Justitiarius.

H. M. Fenger. ( $1850-1930)$, s $\varnothing$ n af proprietær H. F. F. i Augustenborg. 1868 student fra Borgendydskolen på Christianshavn. Kgl. konfessionarius. 
rerne var i det hele ilde lidte og stod os overordentlig fjernt, vi syntes for dem at være „de indfødte“, hvis sæder og sprog, hvis ydre og indre vakte deres forundring, ofte vistnok deres forargelse. Først efterhånden nærmede vi os til hinanden, men en virkelig forståelse blev aldrig bragt til veje." ${ }^{\text {(39) }}$

Hvis man sammenligner den tyske skole i Flensborg 184050 og den danske 1850-64 og tænker på, hvilken af dem der stod højest med hensyn til skoleånd, følelse af fællesskab mellem leder og hans medarbejdere, mellem lærere og ungdommen, må det indrømmes, at den danske tid ikke bærer prisen. Dette står naturligvis noget $i$ forbindelse med, at skoleånd snarere bliver levende $i$ bevægede tider end $i$ mere rolige, men skyldes også i ikke ringe grad lederens person. Lübker var idealisten, den for sin idé begejstrede, opildnende, føreren, Simesen fagmanden, der manglede evnen til at samle og evnen til at varme.

Den bedste skildring af skolen i Flensborg er imidlertid givet af en tysker, Theodor Kaftan (1847-1932), generalsuperintendent i Slesvig (1886-1917). I sine Erlebnisse und B 6 obachtungen (1924) giver han os en ærlig og redelig fremstilling af den tyske dreng $i$ den danske skole.

Hans fader var i 1850 blevet afskediget fra sit præsteembede i Løjt af den dansk-tyske bestyrelseskommission og var død kort tid derefter. Hans moder flyttede med sine to sønner, Theodor og den et år yngre Julius til Husum og i 1858 til Flensborg. Hjemmet var helt tysk.

"Ind i midtpunktet af mit liv trådte skolen. Den var to-sproget, men overvejende dansk. Det betød, at jeg på en eller anden måde (so und so) måtte optage meget af skolevisdommen

s3) En undtagelse næevrer A. D. Jørgensen dog, Christian Monrad: - Han var ganske vist en mand uden fremragende evner eller grundige fagkundskaber, men han var en fyldig udviklet personlighed, fri for alt pedanteri og vigtigmageri, lærlingenes gode kammerat og elskværdige fører. Gennem ham trâdte det danske og nordiske ândsliv os imøde i sin bedste skikkelse, selv udpræget tysksindede drenge indrømmede senere som mænd, at Monrad havde fængslet dem ved sin undervisning og givet dem kærlighed til dansk literatur.x 
i mig på et sprog, som jeg ikke forstod. I begyndelsen voldte det mig store vanskeligheder. Den latinske grammatiks herligheder, algebraens hemmeligheder blev forkyndt for mine oren på flydende københavner-dansk; men jeg var som døv. Jeg så for mine ojne en plante blive dissekeret, men de forklarende ord forstod jeg ikke. Vel brugte engang imellem en venlig lærer et tysk ord eller oversatte en sætning, men for megen hensyn måtte han selvfølgelig ikke tage til en enkelt elev. Kraftigere greb min latinlærer, Hr. Møller, ${ }^{34}$ ) ind. Han lod mig længere tid igennem regelmæssig komme i hans hjem, for først at læse latin på tysk og derefter lidt efter lidt glide over i dansk. Hans billede står endnu for mine øjne, og min taknemmelighed er endnu i dag levende. I det hele taget - man talte $i$ tyske kredse ikke meget godt om de til Slesvig sendte danske embedsmænd; der var også uheldige (unerfreuliche) elementer imellem dem; ganske naturligt: til tjeneste hos en regering, der undertrykker befolkningens naturlige interesser melder der sig ikke altid de bedste - men det vilde være uretfærdigt at nægte, at der også var brave mænd imellem dem. Og af slige var hr. Møller ikke den eneste ved skolen. Der var også nogle, om hvem der også af de danske skolebørn blev fortalt slemme ting. Men måske var det skolesladder. Der herskede delvis ingen god ånd mellem eleverne. Jeg selv er blevet afficeret deraf og har måttet kæmpe alvorligt for igen at komme ud af den.

Men sprogvanskelighederne var i virkeligheden kun begynder-vanskeligheder. Jeg trængte stadig dybere ind $\mathrm{i}$ det mig oprindelig fremmede sprog. Efter nogle år sagde en københavner-dame .... jeg talte dansk som en dansker, hvad der glædede mig meget, thi jeg så allerede dengang i det, at man taler et fremmed sprog slet, ikke nogen rosværdig patriotisme. Da jeg var i prima, i hvilken man skulde holde små foredrag over emner, der var os fortrolige, var det blevet mig eet, om jeg skulde holde et sådant foredrag paa tysk eller på dansk. I det

34) Rud. Møller, f. i København 1821. 1857-64. Collaborator i Flensborg. Privat dimissor i Kbhn. 1864. 1877-91 timelærer ved Metropolitansikolen. † 1895. 
hele taget - hvad der for tusinder af mine snævrere landsmænd gjaldt fra tidligste ungdom, gjaldt for mig på grund af min opdragelse. Vi følte ikke dansk som et fremmed sprog; det var som vort andet modersmål. Det har selv tyske slesvigere, ja navnlig holstenere og sydligere boende tyskere ikke forstået; de vejrede undertiden deri hemmeligt danskersind (Dänentum). Vi tyske nordslesvigere føler os kun helt hjemme der, hvor man taler tysk og dansk.

Men ikke blot det danske sprog trængte mægtigt ind på mig - i skolen herskede dansk ånd. „Fædrelandshistorie“, som vi læste, var dansk (og norsk) historie. I geografitimen karakteriserede $\mathrm{Hr}$. Kjellerup ${ }^{35}$ ) Tyskland gennem verset:

Man sagt mir, Deutschland sei e in Land;

dagegen erheb ich den Einwand:

Ist Charpie denn Leinwand?

Havde manden ganske uret dengang? „Det store fædreland“ gjorde han mig ikke fremmed for ved de ord.

$\mathrm{Ja}$, jeg har været genstand for direkte daniseringsforsøg. Ingemanns romaner blev givet os i hænde. $\mathrm{Nu}$ og da er scenen deri også paa Slesvigs grund, og de var i det mindste dengang af stor betydning for den danske ungdoms nationale opdragelse. De gjorde også indtryk på mit ungdommelige sind. Men dansk gjorde de mig ikke.

Men daniseringsbestræbelserne antog også realere form.

.... Sognepræsten ved St. Hanskirken ${ }^{36}$ ) overraskede en dag min moder ved sit besøg. Han havde hort om hende og hendes forhold, sagde han, han vilde gøre hende opmærksom på, at der på skolen under særlige forhold var fri skolegang; min moder skulde dog andrage derom for sine sønner hos lærerkollegiet, der disponerede derover.

.. Det var svært for min moder med udgifterne. Altså skrev hun ansøgningen, som det var anbefalet hende.

Da fik hun et besøg igen, hr. Monrad .. han sagde, at kol-

ss C. E. Kjellerup (1822—96), 1845-47 med korvetten Galathea. 1854 adjunkt i Flensborg. 1869 adjunkt i Sor $\varnothing$.

36) G. F. A. Graae (1810-86). Præst i Flensborg 1851-64. 
legiet ikke var utilbøjeligt til at gå ind på andragendet, ja måske vilde skaffe hjælp til senere uddannelse (Lehrmittel). Men kollegiet ønskede først at orientere sig om stillingen; derfor var han kommet. Om han måtte forudsætte, at vi efter endt skolegang vilde drage til Kobenhavns universitet? Der vilde man skaffe os Regensen og ogsaa ellers sørge for os, som mulighederne nu lå.

.. Min moder fattede sig hurtigt og svarede venligt, men bestemt: et sådant løfte kunde hun ikke give; hendes sønner havde kastet deres kærlighed paa tyske universiteter.

Noget forstemt rejste hr. Monrad sig; min moder vilde få skriftligt svar på sit andragende. Det blev, at min broder havde fået fri skolegang for et år....

Vore lærere har ikke senere plaget os med anmodninger. Da historielæreren skulde til - det var i den sidste danske sommer - at fortælle os om slaget ved Isted, forlod jeg vi primanere måtte gøre dette uden tilladelse - klassen og blev derude, men længere, meget længere end nødvendigt.. sålænge til den efter min mening så sørgelige fortælling var endt. Så gik jeg igen ind i klassen og satte mig stille på min plads. Hr. Rasch, ${ }^{37}$ ) historielæreren så på mig, smilede, men sagde ikke noget. Det var fint. (gescheit)“

Det er alt i alt et smukt testimonium den tyske dreng har givet den danske skole.

\section{Nederlaget}

I 13 lange år havde Friedrich Lübker ventet på stunden. $\mathrm{Nu}$ mente han, den var kommet. Han nedlagde 1863 sit rektorat i Parchim, for helt at kunne ofre sig for agitation for sagen. Han havde slået sig ned i Braunschweig.

22. december stod han på talerstolen her.

Det var 50 års dagen for den fordrevne hertugs tilbagevenden efter Napoleons nederlag ved Leipzig. Men det handlede talen meget lidt om. Det var opcegning:

Det tyske folk er kaldet at beskytte ret og lovlighed.... Tyskland nedværdiger sig for sig selv, når det støder et af

37) Skrivefejl for Hr. Brasch. 
sine ægte børn ud af døren, martret og forladt, endnu bedende om hjælp klamrende sig til moderens skød. - Vil moderen alligevel for stedse støde hende ud $i$ elendighed?.. Så vil Tysklands grådige fjender komme og flænge dets legeme, tage et stykke her og et stykke der, som det skete for 50 år siden.

Nej, vi vil ikke hengive os til slige mørke tanker .... Vi stiller fuld af glad tillid vort håb til Herren: Som nu for 50 år siden Braunschweigs heltehertug under taknemmelig jubel vendte hjem til sine for det fremmede åg befriede undersåtter, ${ }^{38}$ ) således vil den dag ikke være fjern, hvor den længselsfuldt ventede fyrste, hertugen, vender hjem til landet mellem Elben og Kongeåen, til sit folk, der uden vaklen er blevet ham tro. ${ }^{39}$ )

Om hvad der skete på de uhyggelige - eller festlige dage efter tilbagetoget fra Danevirke, kan rektor Simesen ${ }^{40}$ ) og Theodor Kaftan fortælle os.

"Indtil søndag den 7. februar gik skolen sin uforstyrrede gang; men efter at de sidste af vore tropper havde forladt Flensborg om morgenen, trængte den pøbelhob (mest bestaaende af læredrenge og butikssvende), der havde nedtaget alle kongelige skilter, som de bare i procession omkring $i$ byen, sig med magt ind i skolen og hejsede et trefarvet flag på dettes tårn. Dette foranledigede mig til, så snart den preussiske stab om formiddagen var rykket ind, strax at henvende mig til overgeneralen, for om muligt at få flaget fjernet; tilfældigvis var jeg herved ledsaget af konrektor Schumacher. Dette lykkedes også, men kun for denne dag; thi dagen efter gav general Wrangel atter tilladelse til, at man, det er de der stode i spidsen for de slesvig-holstenske demonstrationer, uhindret turde hejse dette såkaldte slesvigske flag på kirker og offentlige bygninger. I løbet af min samtale med general

38) 1807 var hertug Friedrich Wilhelm blevet fordrevet af Napoleon. 6. november 1813 vendte han under jubel tilbage (efter slaget ved Leipzig). 16. juni 1815 faldt han ved Waterloo. 1864

${ }^{39}$ ) Fr. Lübker: Recht u. Schicksal Sleswig-Holsteins. Braunschweig

$\left.{ }^{40}\right)$ Beretning af 14. Marts 1864 til det slesvigske ministerium. 
Wrangel ytrede denne, at for fremtiden alt $i$ hertugdømmet skulde gå på tysk; og på min bemærkning om umuligheden heraf $i$ den rent dansktalende del nord for Flensborg, svarede han: "einerlei, das ganze Herzogtum soll eine deutsche Provinz werden!“

Om eftermiddagen opsloges en proclamation, i hvilken afgørelsen af alle civile sager overdroges til to civilcommissairer, og foreløbig til den preussiske kammerherre Zedlitz alene. Såsnart denne var kommet til byen, henvendte jeg mig derfor om formiddagen ${ }^{41}$ ) den 8 'de til ham, for om muligt at erholde tilsagn om, at skolens virksomhed turde fortsættes uforstyrret efter de bestående regler og love. Dette erholdt jeg også og meddelte det næste morgen til de forsamlede disciple og lærere".

Efter at have skildret sin jubel ved indtoget fortæller Theodor Kaftan videre:

„Infanteriet drog med fuld musik ned ad Store Gade.... Hvad spillede de? Det var ikke Schleswig-Holstein meerumschlungen. De spillede måske preusser-sangen ${ }^{42}$ ). Den kendte vi ikke. Var det tilfældet, så var det også en passende ouverture til det, som kom.

Om eftermiddagen fik min moder besøg af en veninde. Min broder og jeg sad i værelset ved siden af. Damen sagde til min moder: „Ak, bare vi nu ikke bliver preussere!" Vi hørte det, og jeg sagde til min broder: „Hører du, hvad det tossede fruentimmer siger!“

Samme eftermiddag så vi Wrangel.. drage gennem Røde Port. Senere gik vi forbi skolegården. I porten stod pedellen. Vi sagde til ham: „Er der skole i morgen?“ og han svarede: „Ja, morgen is Sjule, aber alles deuts; der Professor hat gewesen beim General."

Det blev altså først om tirsdagen.

„Forventningsfulde gik vi derhen. Fælles andagt $i$ aulaen kendte vi ellers ikke. Men denne morgen blev vi alle kaldt op

41) Fastelavnsmandag.

42) Vel: Heil dir im Siegerkranz. 
i aulaen. Elevtallet var allerede formindsket. Mange af de ældre disciple, også af mine kammerater, var der ikke mere. .

Rektor Simesen holdt en tale, naturligvis på dansk. Han talte om den tunge tid, der var kommet over vort land. Her var et fredens sted; i fred vilde vi her leve videre, selv om også krigen rasede derude. Han havde været hos civilkommissæren .. og havde fået tilladelse til at føre undervisningen videre på samme måde som før.“ ${ }^{43}$ )

Rektor synes foreløbig at være ret godt tilfreds: „Derefter (o: efter tirsdag d. 9/2.) gik undervisningen nogenlunde uforstyrret denne uge tilende. Det sædvanlige gode forhold imellem disciple og lærere forandredes ikke, og de (iøvrigt ikke mange) trefarvere cocarder og bånd, der medbragtes af disciple, fjernedes ved venskabelig påvirkning af lærere og meddisciple uden anvendelse af magt".

Men de tyske gymnasiaster var af et andet sind end deres rektor; det fortæller Kaftan os:

„Vi havde (efter talen) på fornemmelsen, at vi i skolen nu skulde slutte os sammen som en skare tro danskere, der $i$ stilhed ventede på bedre tider. Det var en rolle, som vi virkelig ikke kunde spille; en del af os forlod aulaen, uden at gå ned i klassen.

Vi tyske primanere rådslog så og besluttede foreløbig at gå i skolen, men samtidig at arbejde på at få en ende på det. Folkeskolerne var allerede taget $i$ brug som lazaretter af danskerne. Det rejste spørgsmålet, om ikke gymnasiet nu kunde tjene tyskerne til det samme formål. Vi henvendte os til en af de tyske førere, boghandler Herzbruck .... nævnede for ham, at rektoren havde påberåbt sig de to sprogs ligeberettigelse, tallet på vore danske og vore tyske timer, pegede på mulighieden at tage gymnasiet $i$ brug som lazaret og bad ham gøre militær-kommandoen opmærksom paa denne mulighed."

Simesen fortsætter $\mathrm{i}$ sin indberetning:

"I lobet af ugen affordredes der samtlige embedsmænd, som betingelse for at kunne blive $i$ deres embede, den er-

43) Med to sprog altså. 
klæring, at de vilde underordne sig civilkommissærernes anordninger og befalinger. Da opfordringen til denne erklærings afgivelse udtalte, at de bestående love og anordninger i det hele vilde blive opretholdte, så anså skoles lærere det for deres pligt at afgive den forlangte erklæring for at bidrage til, at skolens virksomhed om muligt kunde fortsættes under nogenlunde tålelige forhold.

Men umiddelbart efter at disse erklæringer vare afgivne, blive om løverdagen den 13. februar alle klasseværelserne rekvirerede til lazaret af tre preussiske stabslæger. Jeg udbad mig rekvisitionen skriftlig, hvilket også lovedes mig; men da den endnu ikke var modtaget ved undervisningens slutning løverdag middag, så kunde der ingen regelmæssig meddelelse ske derom til lærere og disciple, og der sagdes dem blot, at undervisningen sandsynligvis vilde blive standset, og at man forsåvidt man ikke havde erholdt nærmere besked om søndagen, måtte mødemandag morgen. . Uden at jeg imidlertid da eller senere erholdt den begærede og lovede skriftlige rekvisition, sendtes der søndag morgen arbejdsfolk fra militærcontoiret for at bortflytte skoleinventariet, der bragtes op på loftet $i$ hovedbygningen. Ved dette arbejde måtte skolens pedel, såvel som jeg selv, være nærværende, så at der ingen tilsigelse til lærerne om søndagen kunde finde sted, medens det dog rygtedes til de fleste lærere og disciple, der straks samme dag afhentede deres tavler og bøger.

Derimod henvendte jeg mig strax skriftlig til civilkommissæren for at meddele rekvisitionen og at formå ham til at drage omsorg for, at skolegerningen standsedes så lidt som muligt. Tillige henvendte jeg mig mundtlig til overpræsidenten, kammerherre v. Rosen, med forespørgsel om, hvorvidt han .... troede sig i stand til at kunne forskaffe skolen et andet brugeligt lokale til at læse i; men da han erklærede, under de daværende forhold ikke at se nogen mulighed til, at byen skulde kunde eller vilde skaffe det onskede lokale tilveje. så blev der intet andet til overs end midlertidigt at standse undervisningen, hvorimod jeg enkeltvis opfordrede lærerne til i det mindste 
den resterende del af måneden i deres private boliger at vejlede de disciple, der henvendte sig til dem, til at benytte deres tid så godt som muligt. En sådan privat vejledning uden betaling gaves også af flere lærere."

Imidlertid var rektor Lübker kommet tilbage til Flensborg: han skulde undersøge de tre lærde skolers tilstand og gøre indberetning herom til civilkommissionen.

Efter 14 års forløb var han atter $\mathrm{i}$ den by, han var fordrevet fra. $\mathrm{Nu}$ var han på vej til den skole, som han følte var hans.

"Mandagen den 22'de om aftenen indfandt forhenværende gymnasialdirector dr. Lübker sig for mig og foreviste mig et commissorium fra civilkommissærerne .... Til grundlag for undersøgelsen erholdt han udleveret et exemplar af skolens programmer siden $1851 \mathrm{og}$ to års skriftlige examensarbejder af abiturienterne."

$\mathrm{Nu}$ stod afgørelsen for døren.

„Da jeg nu troede at kunne gøre regning på, at der ikke ville blive foretaget skridt imod skolens lærere, forinden denne undersøgelse og indberetning var sket, og at der dertil dog rimeligvis vilde medgå en 8 dages tid, så sammenkaldte jeg strax den følgende dag de 8 disciple, der midt i marts skulde have bestået deres realafgangsexamen, og tilbød dem at benytte disse dages frist til at få afgangsexamen afholdt. Den skriftlige del af denne examen tilendebragtes da til den 28. februar, og mandag den 29. samt tirsdagen den 1. marts afholdtes i et værelse paa loftet og et i kælderen mundtlig examen, der vilde være bleven tilendebragt den følgende dag, idet der kun manglede to fag: historie og religion, dersom ikke.... “

I den stund modtog rektor skrivelsen fra civilkommissionen (af 29. februar):

"De mangfoldige klager og besværinger, som er indløbet over tilstanden i Flensborg lærde og Realskole hertil, har bevæget den øverste civilmyndighed til at lade sig tilstille en indgående beretning om skolens tilstand. En omhyggelig undersøgelse af det indsamlede materiale har givet til resultat, at der til grund for denne skoles komplicerede og ofte omarbejdede undervis- 
ning hverken har ligget et fast pædagogisk eller et holdbart didaktisk princip, men ene og alene et nationalt-politisk, som ganske og aldeles var beregnet paa den successive og fuldstændige danisering af den slesvigske befolkning, så at de gældende normative bestemmelser .. blev ladet ganske ude af betragtning, så at den klassiske dannelse har måttet sygne hen, undervisningen i tysk $i$ højeste grad er blevet forsømt, og heller ikke realskolen har taget noget nævneværdigt opsving.

Denne skoles tilstand har lærerne delvis ansvaret for; de har — hvad enten det nu er på grund af mangel på evner eller for at forfølge politiske bihensigter - intet hensyn taget til skolens egentlige kald. For at denne igen kan vinde sin velsignelsesrige indflydelse og indtage den plads, der sømmer sig den, til befolkningens vel, er en reorganisation af denne og en fjernelse af lærerne simpelt hen nødvendig."

Med skrivelsen fulgte afskedigelsesbreve til rektor og 16 lærere.

Dagen efter forlangtes aflevering af skolens inventar og samlinger (biblioteket var nu på 10.000 bind) til dr. Lübker. Det skete den 7. ds.

9. februar forlod Simesen byen (nu var også rektorboligen taget ind til lazaret), og lærerne efterhånden i løbet af måneden. Schumacher, Dittmann og tre andre tyske lærere blev ved skolen. Monrad vilde ikke give op, han blev ved sin privatskole i Flensborg.

Den dom, der fra tysk side fældedes over den danske skole, var, som det ses, meget hår. Men om den kan det siges, at den er blevet til $i$ en kamptid, og at den slet intet hensyn tager til de værdier, der var bibragt eleverne fra dansk kulturliv, sprog, litteratur, historie og geografi. En mand, der kendte den danske skole bedre end dr. Lübker var Theodor Kaftan; hans dom lyder: „Rektor Lübker dømte, da han lærte os at kende: vi primanere var i de gamle sprog ikke længere end tyske sekundanere. Deri havde han visselig ret. Jeg er, trods det at jeg tog den tyske prima med, aldrig blevet rigtig hjemme i den klassiske oldtid. Det 
beklager jeg. Men jeg stiller med fuld overbevisning følgende op derimod: at vokse op med to sprog og to litteraturer, som vi har gjort det, også det har for den åndelige udvikling en særlig værdi.“

Flensborg lærde og Realskole havde ophørt at eksistere.

Skolen atter tysk.

1. marts modtog dr. Lübker den officielle udnævnelse til rektor ved skolen. $\left.{ }^{4}\right)$ Lige før påske skete den højtidelige indvielse ,in deutschem Sinn und Geiste", skønt jo skolebygningen stadig blev brugt som lazaret. I juli overtoges den atter.

Der ansattes 8 nye lærere, 6 var fra Flensborg eller Sydslesvig, 2 fra Holsten. Alle var de uddannet i Holsten (Kiel) eller det øvrige Tyskland, og alle havde de haft ansættelse sydpå eller været privatlærere i Flensborg. Lærerne var altså nu mere hjemstavns-betonede end i den danske tid.

Dansk forsvandt fra timerne; de dansktalende børn, mest børn af embedsmænd, rejste for en stor del bort, og for børn fra dansksindede flensborghjem var overgangen mindre voldsom, da deres hjemmesprog jo var tysk.

At der var nogen triumfering, kan man vel ikke undre sig over: „Særlig anledning til fælles opløftelse af hjerte og sind .. gav mindet om den for et år siden tilkæmpede sejr ved Oversø og de forbundne hæres indtog d. 6. februar f. år," og Lübker taler i den første årsberetning (1865) også om "den guddommelige visdoms forunderlige førelse, som i løbet af det foregående år har gengivet det hårdt prøvede Slesvig-Holsten dets gamle ret og dets frie selvstændighed ved de tyske stormagters glorrige sejre."

Preussens sejr over Østrig i 1866 fik følger også for den slesvig-holstenske skole i Flensborg.

20. februar 1867 aflagde lærerne troskabsed til kong Wilhelm, og „hans majestæt kongens fødselsdag blev den 22. marts højtideligholdt $\mathrm{i}$ latinskolens auditorium. Gymnasiekoret ind-

4) Den 1851 afskedigede tyske Flensborg-lærer C. P. Jessen (s. $145 \mathrm{ff}$ ) blev rektor i Haderslev. 
ledte med Salvum fac regem, dr. Wallich holdt festtalen, og til slut istemte hele forsamlingen Heil dir im Siegerkranz."

Årsdagen derefter lød fra talerstolen ægte preussiske ord: „... En side til, hvorpå vor skoles opdragelse må lægge mere vægt end hidtil, er udviklingen af elevernes fædrelandsfølelse. De unge må frem for alt opnå kendskab til det nye fædreland, som de tilhører. De må på det inderligste gøres fortrolige med Preussens historie, med dets land og dets folk. En sådan viden skaber forståelse og interesse for det nye fædreland; fører vi eleverne gennem den preussiske stats rige udvikling, fra dens små tilløb til bydende stormagt, lærer vi dem det hohenzollerneske fyrstehus' storhed og betydning at kende, så vil ærefrygt og pietet mod kongen slå rødder i deres sind, den konge, i hvem Preussens verdenshistoriske mission nu af guddommelig nåde kulminerer."

Så omskiftelig har Flensborg lærde og Realskoles historie været $\mathrm{i}$ disse bevægede år:

Tysk, „helstatlig“ (før 1848) - slesvig-holstensk - dansk slesvig-holstensk - preussisk.

Og præget, ånden og tonen skifter atter $\mathrm{i}$ årene efter 1918 - og skifter igen - 